\title{
Differences in serum concentration of vascular cell adhesion molecules (sVCAM-1) in patients treated with percutaneous balloon dilatation with stent implantation and patients treated with paclitaxel-coated balloon
}

\section{Đeiti Prvulović*, Irzal Hadžibegović, Božo Vujeva, Krešimir Gabaldo, Ognjen Čančarević}

General Hospital "Dr. Josip Benčević", Slavonski Brod, Croatia
RECEIVED:

February 8, 2016

ACCEPTED:

February 20, 2016

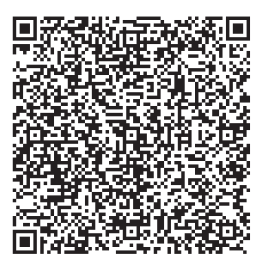

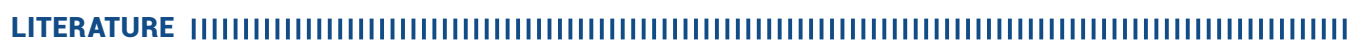

1. Costa MA, Simon DI. Molecular basis of restenosis and drug-eluting stents. Circulation. 2005;111:2257-73. DOI: http://dx.doi.org/10.1161/01.CIR.0000163587.36485.A7

2. Kleber FX, Rittger H, Bonaventura K, Zeymer U, Wöhrle J, Jeger R, et al. Drug-coated balloons for treatment of coronary artery disease: updated recommendations from a consensus group. Clin Res Cardiol. 2013:102(11):785-97. DOI: http://dx.doi.org/10.1007/s00392-013-0609-7

3. Scheller B. Opportunities and limitations of drug coated balloons in interventional therapies. Herz. 2011;36(3):232-9. Dol: http://dx.doi.org/10.1007/s00059-011-3462-3 